\title{
Examining Customer Satisfaction at the Point-of-Purchase Phase: A Study on Malaysian e-Consumers
}

\author{
Noorshella Binti Che Nawi ${ }^{1}$, Abdullah Al Mamun ${ }^{1} \&$ Nursalihah Ahmad Raston ${ }^{1}$ \\ ${ }^{1}$ Faculty of Entrepreneurship and Business, Universiti Malaysia Kelantan, City Campus, Kota Bharu, Kelantan, \\ Malaysia \\ Correspondence: Noorshella Binti Che Nawi, Faculty of Entrepreneurship and Business, Universiti Malaysia \\ Kelantan, City Campus, 16100 Kota Bharu, Kelantan, Malaysia. E-mail: norshella@umk.edu.my
}

Received: December 13, 2014 Accepted: April 26, 2015 Online Published: June 13, 2015

doi:10.5539/ass.v11n16p88

URL: http://dx.doi.org/10.5539/ass.v11n16p88

\begin{abstract}
Customer satisfaction is considered the essence of enterprise success, especially in the competitive online business environment. This study aimed to examine how the selected key factors, i.e., general belief, information quality, website design, merchandise attributes, payment transaction, security and privacy, delivery service, and customer service, contribute to overall satisfaction among the customers of small online apparel businesses in Malaysia. This study used a cross-sectional design and complete data was collected from 765 customers who purchased apparel online at the point-of-purchase. The finding reveals that general belief, information quality, website design, payment transaction, security and privacy, delivery service, and customer service have a positive significant effect on overall satisfaction. In order to sustain in the competitive online business environment, small online apparel businesses in Malaysia should therefore focus on operational strategies on the dimensions of service quality, which would lead to an improvement in overall customer satisfaction.
\end{abstract}

Keywords: customer satisfaction, point-of-purchase, apparel online, e-Consumers, Malaysia

\section{Introduction}

Given the advancement in information technology, online shopping has become a popular activity. Many marketers are beginning to develop online products for marketing. Until today, the central concern of marketers is still focused on the concepts of satisfaction and loyalty to a merchant's website. Electronic commerce, commonly known as e-commerce, is a type of industry where the buying and selling of products or services is conducted over electronic systems such as the Internet and other computer networks. In recent years, electronic commerce has entered a platform of exponential growth. In addition, the use of the Internet in the consumer decision-making process has caused traders to make greater use of this tool. While consumer behavior in e-commerce seems to be a complex subject, the consumer expectations are changing, challenging traditional patterns of supply of commercial websites. Satisfaction is a response to a perceived discrepancy between prior expectations and perceived performance after consumption (Eid, 2011; Lau, Kwek, \& Tan, 2011). Customer satisfaction is defined by how satisfied one is with the products/services. Thus, satisfaction is extremely important to marketers of products and services. This is because when a customer is satisfied, it will bring $\mathrm{him} / \mathrm{her}$ to a positive purchase intention such as repurchase, positive word-of-mouth and loyalty in the long term.

Customer satisfaction plays a crucial role in sustaining in the marketplace (Garver \& Gagnon, 2002); therefore, it is important to ensure that customers are satisfied. If not, retailers will lose their market. Few studies have been done that focus on uncovering the underlying constructs of customer satisfaction, however, the impact of payment was seldom touched (Xia et al., 2008). Ladhari (2010) found that consumer satisfaction (e-satisfaction) must be concerned with all aspects of issues that arise before, during, and after the delivery of the service. Meanwhile, another research on online customer satisfaction claims that advertisements, product quality, brand names, and prior shopping experiences play a significant role in customer satisfaction among online shoppers (Mumtaz et al., 2011). Earlier studies on service quality measures commonly take into account the entire purchase and even the after-purchase process (Muyllea et al., 2004; Parasuraman et al., 2005; Kim et al., 2006; Bauer et al., 2006). However, lack of empirical research has been done at the point-of-purchase phase and in finding out how this phase affects customer satisfaction. This study therefore proposes that e-service quality dimensions consist of general belief, information quality, merchandise attributes, transaction capability and 
payment, security and privacy, expected delivery and expected customer service, and thus developed a research model for understanding the perceptions of rational customers at the time of purchase of products through online services.

\section{Literature Reviews}

\subsection{General Belief about Online Shopping}

Belief about online shopping has been recognized as one factor that affects people's online purchase. Fishbein and Ajzen (1975) defined belief is an attitude, which refers to a person's favorable or unfavorable evaluation of an object. In other word, it corresponds to the information he/she has about the object. The object of belief can be a person, a group of people, an institution, behavior, a policy or an event, and the connected attribute may be any object, trait, property, quality, characteristic, outcome or event. However, Leen and Ramayah (2011) defined that beliefs are the feeling towards some aspects of the world, which correspond to a person's self-understanding and environment and lead to the person's attitude, intention, and behavior. They added that perceived usefulness and perceived ease of use are two beliefs that determine the likelihood of online shopping as argued by Vijayasarathy (2004) and Yoon (2010).

\subsection{Information Quality}

According to Chen et al., (2012), one of the important elements in measuring the success of the information system is by providing good information quality. Lopes and Galletta (2006) also indicate that good content of information influences the consumers' willingness to pay for the products. Wu (2011) conducted a study on sharing quality information in the supply chain. The finding shows that sharing quality information with the buyer impacts its market. In other words, suppliers are required to share information with buyers (e.g in automobile industry) on where the parts have been produced and this sharing of information helps the buyer to know the quality of the part that is being used in the automobile industry.

\subsection{Website Design}

Kim, Hwang and Fesenmaier (2005) estimate that people normally widen their impression towards an object within two to seven seconds. They added that if people do not satisfy at the time they browse the website, they can easily leave the website and go to competitor website. According to Han and Mills (2006) the visual items at the website such as visual appeal and information transfer (e.g. color, logo) and visitor's experience and reliability (e.g. search tool, accurate link) can raise the interest of online travelers to browse the tourism website. Recent study by Chow et al., (2014) which focused on library website designs believes that a library website needs to be easily navigable, including obvious signs that quickly lead the user to the information searched for. Besides, the websites need 25-35 seconds to proof to the users that the information they are looking for is available.

\subsection{Merchandise Attributes}

Web merchants who offer a wide range of assorted products seem to be more successful. In addition, Xia et al. (2008) indicated that a wider range of merchandise together with low price could affect customer satisfaction in the context of online setting. Guo et al. (2012) also found that merchandise attributes have significance in determining customers' satisfaction with the online shopping experiences. Syzmanski and Hinse (2000) also concluded that having more choices could be one of the attractions of websites, which in turn leads to satisfaction among online shoppers.

\subsection{Payment Transection}

Guo et al. (2012) stated that online retailers normally offer many types of online payment (e.g. credit card, payment with cash and telegraphic remittance) and customers normally choose their preferred type of payment not only based on convenience but also based on security. For instance, for cash payment, online retailers offer COD (cash on delivery) when they deliver the product to customers. In other words, customers pay for the product upon meeting with the owner of the business. This is argued by Grace and Chia-Chi (2009) who found that customers used certain criteria to evaluate the usefulness and ease of use for a particular website, including information search, Internet search, Internet subscription and payment methods. Hence, online retailers should make the payment procedure easy to increase the level of customer satisfaction (Grace \& Chia-Chi, 2009).

\subsection{Security and Privacy}

Security system is one of the most important issues especially in dealing with the online environment setting. Yuan and Kyounghee (2013) proposed three types of privacy beliefs, which are disposition of privacy concern, online privacy concern risk, and website privacy concern. The finding revealed that there is a positive influence 
on disposition with privacy concern and website privacy concern. Meanwhile, website privacy concern is the predictor of intentions to reveal the information and transact on the website.

\subsection{Expected Service Delivery}

One of the contributions of this study is to differentiate between service delivery and customer service at difference phases. Based on Zeithaml et al. (2002), having products in stock, delivering the products within the time frame promised and accuracy of service promises are attributes of this fulfillment's factor. They added that delayed delivery may have a negative effect on satisfaction. According to Yang and Fang (2004), two keys of service quality connected to customer satisfaction are the accuracy of the order fulfillment and keeping service promises. Not simply keeping promises about order delivery, the efficiency of service delivery has also been evaluated by the proper condition of the product (Meuter et al., 2000) and item presentation evaluation The product should be delivered well-packaged and customers will receive the product seen on the website (Parasuraman et al., 2005). This attribute is difference with the service delivery in post-purchase stage where service delivery is measured after customers have received their products while expected service delivery is measured when customers place their order. This suggests that these elements play a different role at every stage, and the research was planned on this basis.

\subsection{Expected Customer Service}

Similar with expected service delivery, expected customer service is measured at the time customer purchases the product and it is different from customer service where its measure after customer received the products. Expected customer service is more than policies, procedures and responsiveness in handling complaints. It also refers to the return policy, customer's right to change and that problems can be solved. At this stage too, customers are offered many interactive communications with the company. For instance, customers can use the chat room, email, telephone, bulletin board and feedback forms to communicate with the company (Massey \& Levy, 1999). According to Teo et al. (2003), interactivity features have a significant relationship with the consumers' perceived value. Indeed, Zeithaml (1988) added that customer value has been recognised as the key for businesses to succeed.

\section{Methodology}

\subsection{Population and Sampling}

The target population for this study was defined as individuals who purchased apparel online at point-of-purchase through Blogspots and websites in Malaysia. To establish the sample frame, a list of Blogspots and websites selling apparel online was obtained from the Internet. The respondents were obtained from the owners of the online shops. The respondents were approached by the researcher for permission to email the questionnaire online link to them and the researcher assured them that their particulars would be kept confidential and that their particulars would be deleted once the survey was completed. Random sampling was used as this research sought to generalize the results obtained as much as possible from the Internet users who purchased online.

\subsection{Research Instrument and Facilitating Software}

Online survey using the SurveyMonkey platform was chosen in order to collect the data for this study. The questionnaire was developed using a 7-point Likert scale ranging from 1 (strongly disagree) to 7 (strongly agree) Due to the respondents being non-English speakers, translation was done by a language expert. The questionnaire design was straightforward and comprehensible, avoiding ambiguities, estimations and leadings and presumptive questions.

\subsection{Generalization of Items in Questionnaire}

Items for 'general belief' about online shopping were adopted from Hirst and Ashwin (2009), Rajamma and Neeley (2005) and Swinyard and Smith (2003). 'Information quality' of purchase website was operationalized by the following variables: accuracy, comprehensibility, completeness, and relevance. These items were adapted from previous research studies by Muyllea et al. (2004). The 'website design' construct was operationalized by website structure, navigation, combination of colours, and ease of use. These items were adopted from Kim and Stoel (2004) and Muyllea et al. (2004). 'Merchandise attributes' was divided into aspects of purchase incentive and product variety, being adapted from Xia et al. (2008). 'Security and privacy' issues were considered and adapted from Wolfinbarger and Gilly (2003).

Items from Kim and Stoel (2004) and Xia et al. (2008) were adapted for 'transaction capability and payment'. The interviews revealed that to satisfy their customers, the owners of the online apparel businesses offered 
customers a minimum deposit requirement, provided many options for payment such as post office remittance, online payment and cash on delivery (COD) and also various options in receiving proof of payment (e.g. email, SMS etc.). These added values are incorporated into the questionnaire in order to appropriately measure the 'transaction capability and payment' construct. 'Expected service delivery' was adapted from Rossiter (2007) and three items were developed and added by the researcher to refine the definition of this construct based on responses from the in-depth interviews. The interviews revealed that the major delivery activities and expectations specific to online apparel retailers in Malaysia were that consumers expect a standard price for a delivery service, expect online apparel retailers to provide clear terms and conditions for delivery service and also expect to be rewarded through this service for purchasing more items. These activities were incorporated into the questionnaire in order to appropriately measure the 'expectation delivery service' construct. The interview's finding also assisted in refining the 'expected customer service' questions offered by Wolfinbarger and Gilly (2003) in their study used in the United States. For instance, the findings from question 2 were extracted into four questions in the survey. Based on the interview's finding, online business retailers offered customers a refund if they were not satisfied with the purchase, guaranteed an exchange if customers were not satisfied with the product, provided online tracking for products, and customers could contact them through many options such as by chat room, email and phone. These findings guided the respondents in the Malaysian context in understanding the referred items.

\section{Summary Of Findings}

\subsection{Respondents Demographic Characteristics}

A complete data was collected from 765 customers who purchased apparel online. As presented in Table 1, among the total 765 respondents, 89 respondents or $11.6 \%$ are male. The percentage is much higher for the female respondents, which is equivalent to 676 respondents or $88.4 \%$. Most of these respondents are single (506 or $66.1 \%$ ), followed by married ( 243 or $31.8 \%$ ), and others (16 or $2.1 \%$ ).

Table 1. Respondent's demographic characteristics

\begin{tabular}{|c|c|c|c|c|c|}
\hline Category & $\mathrm{n}$ & $\%$ & Category & $\mathrm{n}$ & $\%$ \\
\hline Respondent's Age & & & Gender & & \\
\hline$<18$ years old & 15 & 2.0 & Male & 89 & 11.6 \\
\hline 18 to 24 years old & 305 & 39.9 & Female & 676 & 88.4 \\
\hline 25 to 30 years old & 334 & 43.7 & Total & 765 & 100.0 \\
\hline 31 to 36 years old & 84 & 11.0 & & & \\
\hline 37 to 42 years old & 16 & 2.1 & Marital Status & & \\
\hline$>42$ years old & 11 & 1.4 & Single & 506 & 66.1 \\
\hline \multirow[t]{2}{*}{ Total } & 765 & 100.0 & Married & 243 & 31.8 \\
\hline & & & Other & 16 & 2.1 \\
\hline Respondent's Education & & & Total & 765 & 100.0 \\
\hline Secondary & 34 & 4.4 & & & \\
\hline Certificate & 33 & 4.3 & Respondent's Ethnicity & & \\
\hline Diploma & 139 & 18.2 & Malay & 618 & 80.8 \\
\hline Degree & 426 & 55.7 & Chinese & 71 & 9.3 \\
\hline Master & 109 & 14.2 & Indian & 37 & 4.8 \\
\hline PHD & 18 & 2.4 & Other & 39 & 5.1 \\
\hline Others & 6 & .8 & Total & 765 & 100.0 \\
\hline Total & 765 & 100.0 & & & \\
\hline \multirow{2}{*}{\multicolumn{3}{|c|}{$\begin{array}{l}\text { How much would you normally spend to purchase } \\
\text { apparel online? }\end{array}$}} & \multicolumn{3}{|c|}{$\begin{array}{l}\text { How many times have you used the online store in the last } \\
6 \text { months? }\end{array}$} \\
\hline & & & $1-2$ & 167 & 21.8 \\
\hline Below RM50 & 123 & 16.1 & $3-5$ & 267 & 34.9 \\
\hline RM51-RM150 & 304 & 39.7 & $6-10$ & 189 & 24.7 \\
\hline RM151-RM250 & 156 & 20.4 & Above 10 & 142 & 18.6 \\
\hline RM251-RM350 & 92 & 12.0 & Total & 765 & 100.0 \\
\hline
\end{tabular}




\begin{tabular}{llllll}
\hline Category & $\mathrm{n}$ & $\%$ & Category & $\mathrm{n}$ & $\%$ \\
\hline RM351-RM450 & 48 & 6.3 & & & \\
RM451-550 & 16 & 2.1 & Monthly Income & 163 & 21.3 \\
RM551-RM650 & 9 & 1.2 & Below RM 500 & 226 & 29.5 \\
Above RM651 & 17 & 2.2 & RM501-RM2000 & 301 & 39.3 \\
Total & 765 & 100.0 & RM2001-RM 4000 & 59 & 7.7 \\
\multicolumn{7}{l}{ How much did you spend on this current purchase? } & RM6001-RM8000 & 13 & 1.7 \\
Below RM50 & 184 & 24.1 & Above RM10000 & 3 & .4 \\
RM51-RM150 & 296 & 38.7 & Total & 765 & 100.0 \\
RM151-RM250 & 127 & 16.6 & & & \\
RM251-RM350 & 58 & 7.6 & & & \\
RM351-RM450 & 33 & 4.3 & & & \\
Above RM451 & 67 & 8.7 & & & \\
Total & 765 & 100.0 & & & \\
\hline
\end{tabular}

Most of the online consumers surveyed in this study are aged between 18 to 30 years old. Among the total 765 respondents, 426 or $55.7 \%$ of the total respondents have completed their bachelor degree, followed by 139 or $18.2 \%$ who have completed their Diploma and 109 or $14.25 \%$ who have completed their Master degree. Respondents' level of education clearly indicates that relatively higher educated consumers purchase products online rather than through traditional shopping. As per the ethnicity of respondents, out of 765 respondents, 618 or $80.8 \%$ is Malay, followed by 71 or $9.3 \%$ Chinese, 37 or $4.8 \%$ Indian and 39 or $5.9 \%$ others. The percentage of Malay and Chinese ethnic groups $(80.8 \%$ and $9.3 \%)$ in the study is different than that of the national population where $67.4 \%$ are Malay and $24.6 \%$ Chinese (Department of Statistics, 2010). This indicates that among the different ethnic groups, a relatively higher proportion of Malay consumers purchase products online compared to other ethnic groups. As per the income, 690 or $90.19 \%$ of the total respondents reported that their income is below RM4000; among them 389 respondents' income is below RM2000. With regard to the number of times respondents purchased apparels online in the last six months, 167 or $21.8 \%$ respondents reported that they purchased 1 to 2 times only; followed by 267 or $34.9 \%$ respondents who purchased 3 to 5 times, 189 or $28.7 \%$ respondents who purchased 6 to 10 times, and 142 or $18.6 \%$ respondents who purchased more than 10 times. As per how many respondents spend while purchasing apparels online, the highest proportion of respondents (304 or $39.7 \%$ ) reported that they spent between RM51 to RM150, followed by 156 or $20.4 \%$ respondents who spent between RM152 to RM250. A total of 182 respondents or $23.7 \%$ respondents spent more than RM250. Table 1 presents the data on how much respondents spent in their last purchase. A total of 583 out of 765 respondents or $76.21 \%$ spent less than or equivalent to RM250 only. This indicates that, when it comes to purchasing expensive or high quality apparels, which commonly cost more than RM250, most online consumers may prefer traditional shopping compared to online shopping.

\subsection{Descriptive and Reliability Analysis}

Table 2. Reliability and descriptive analysis

\begin{tabular}{lllll}
\hline Factors & Number of items & Mean & Standard Deviation & Cronbach's Alpha \\
\hline Satisfaction & 3 & 5.3386 & 1.00882 & 0.931 \\
Website Design & 8 & 5.3399 & 1.02561 & 0.949 \\
Information Quality & 5 & 5.0635 & .94945 & 0.905 \\
Security and Privacy & 4 & 5.3972 & .93136 & 0.921 \\
Merchandise Attributes & 5 & 4.9886 & .96864 & 0.856 \\
Expected Customer Service & 3 & 5.2997 & .97085 & 0.850 \\
Transaction and Payment & 4 & 5.0915 & 1.04487 & 0.856 \\
General Belief & 3 & 5.1853 & .98345 & 0.801 \\
Expected Delivery Service & 4 & 5.1586 & 1.04291 & 0.825 \\
\hline
\end{tabular}


Reliability analysis was performed to test the internal consistency of the dependent variable (consumer satisfaction), as well as the independent variables (general belief, information quality, website design, merchandise attributes, transaction and payment, security and privacy, expected delivery service, and expected customer service). The findings, as presented in Table 2, indicate that the measurement instruments for each factor are reliable since the Cronbach's alpha values range between $0.801-0.949$ which exceed 0.7 as the recommended value.

As presented in Table 2, the mean value for the satisfaction measure is 5.339, general belief measure is 5.340, information quality measure is 5.064, website design measure is 5.397, merchandise attributes measure is 4.989 , payment transection measure is 5.300 , security and privacy measure is 5.092 , delivery service measure is 5.185 , and customer service measure is 5.1586 .

\subsection{Testing Assumptions}

In the absence of the fit test, the probability of the $\mathrm{F}$ test statistic $(\mathrm{F}=6.438)$ was $p=0.519$, which is higher than the chosen $5 \%$ level of significance, indicating that a linear regression model is appropriate as it satisfies the linearity assumption.

Table 3. Lack of fit tests

\begin{tabular}{llllll}
\hline Source & Sum of Squares & $\mathrm{df}$ & Mean Square & $\mathrm{F}$ & Sig. \\
\hline Lack of Fit & 279.016 & 705 & .396 & 6.438 & .519 \\
Pure Error & 2.213 & 36 & .061 & & \\
\hline
\end{tabular}

The $p$ value for the Levene's test for equality of variance for dependent and independent variables are presented in Table 4. As the $p$ values for all variables are more than the chosen $5 \%$ level of significance, equality of variances can be assumed. This finding satisfies the assumption of homoscedasticity.

Table 4. Levene's test for homogeneity of variance

\begin{tabular}{lllllllll}
\hline Test/Variables & $\begin{array}{l}\text { General } \\
\text { Belief }\end{array}$ & Info-Quality $\begin{array}{l}\text { Website } \\
\text { Design }\end{array}$ & $\begin{array}{l}\text { Merchandise } \\
\text { Attributes }\end{array}$ & $\begin{array}{l}\text { Payment } \\
\text { transection }\end{array}$ & $\begin{array}{l}\text { Security } \\
\text { Privacy }\end{array}$ & $\begin{array}{l}\text { Delivery } \\
\text { Service }\end{array}$ & $\begin{array}{l}\text { Customer } \\
\text { Service }\end{array}$ \\
\hline F & .180 & .705 & .396 & 1.203 & .035 & 0.019 & 1.532 & 1.061 \\
Sig. & 0.495 & 0.065 & 0.214 & 0.974 & 0.219 & 0.239 & 0.049 & 0.173 \\
\hline
\end{tabular}

The value of the Durbin-Watson statistic ranges from 0 to 4 . As a general rule of thumb, the residuals are not correlated if the Durbin-Watson statistic is approximately 2, and an acceptable range is 1.50 to 2.50 . The value of the Durbin-Watson statistic is 1.942 (Table 7), which indicates that the assumption of independence of errors is satisfied. Furthermore, the value of Variance Inflation Factor (VIF) for all variables in the study, as noted in Table 8 , is less than 10 while the Tolerance value exceeds 0.2 , therefore satisfying the assumption of the absence of multicollinearity.

\subsection{Correlation Analysis}

Table 5. Correlation analysis

\begin{tabular}{|c|c|c|c|c|c|c|c|c|c|}
\hline Variables & SA & GB & IQ & WD & MA & TP & SP & DS & CS \\
\hline SA & 1 & & & & & & & & \\
\hline GB & $.510^{* *}$ & 1 & & & & & & & \\
\hline IQ & $.543^{* *}$ & $.544^{* *}$ & 1 & & & & & & \\
\hline WD & $.522^{* *}$ & $.428^{* *}$ & $.533^{* *}$ & 1 & & & & & \\
\hline MA & $.476^{* *}$ & $.440^{* *}$ & $.450^{* *}$ & $.524^{* *}$ & 1 & & & & \\
\hline TP & $.608^{* *}$ & $.464^{* *}$ & $.504^{* *}$ & $.554^{* *}$ & $.496^{* *}$ & 1 & & & \\
\hline SP & $.643^{* *}$ & $.474^{* *}$ & $.533^{* *}$ & $.513^{* *}$ & $.529^{* *}$ & $.697^{* *}$ & 1 & & \\
\hline DS & $.573^{* *}$ & $.409^{* * *}$ & $.448^{* *}$ & $.506^{* *}$ & $.547^{* *}$ & $.720^{* *}$ & $.668^{* *}$ & 1 & \\
\hline $\mathrm{CS}$ & $.590^{* *}$ & $.394^{* *}$ & $.417^{* *}$ & $.439^{* *}$ & $.486^{* *}$ & $.646^{* *}$ & $.625^{* *}$ & $.658^{* *}$ & 1 \\
\hline
\end{tabular}

SA: Satisfaction; GB: General Belief; IQ: Information Quality; WD: Website Design; MA: Merchandise Attributes; TP: Payment transection; SP: Security and Privacy; DS: Delivery Service; and CS: Customer Service

** Significant at $1 \%$ level of significance 
The correlation analysis presented in Table 5 indicates the association between variables. At $5 \%$ level of significance, only one pair of independent variables, 'delivery service' and 'payment transection' are strong and statistically significant $(\mathrm{r}=0.720, p<0.01)$. Table 5 shows that all the other independent variables have a moderate relationship with satisfaction and with each other.

\subsection{Regression Analysis}

The $r^{2}$ value, as presented in Table 7, determines the amount of explained variation in satisfaction (dependent variable) from the eight variables on a range of $0-100 \%$. Thus, the study indicates that the $r^{2}$ value after omitting the outliers become better which is $61.7 \%$ of the variation in satisfaction and is accounted for through the combined linear effect of the predictor variables, i.e., general belief, information quality, website design, merchandise attributes, payment transection, security and privacy, delivery service, and customer service.

Table 6. Model summary

\begin{tabular}{|c|c|c|c|c|}
\hline Model & R Square & Adjusted R Square & Std. Error of the Estimate & Durbin-Watson \\
\hline Presence of outliers & $.741^{\mathrm{a}} .550$ & .545 & .68050 & 1.936 \\
\hline After eliminate outliers & $.786^{\mathrm{a}} .617$ & .613 & .61606 & 1.942 \\
\hline
\end{tabular}

As noted in ANOVA (Table 7), the sum of squares is the total variance (734.552), which includes regression (453.323) and residual (281.229). The total variance is partitioned into the variance that can be explained by the independent variables (regression) and the variance, which cannot be explained by the independent variables (residual). The $p$-value of ANOVA F-test is 0.000 , which is less than the chosen $5 \%$ level of significance, indicating a good model fit. This indicates that at least one of the eight variables: general belief, information quality, website design, merchandise attributes, payment transection, security and privacy, expected delivery service, and expected customer service can be used to model the satisfaction among online apparel consumers in Malaysia.

Table 7. Analysis of variance

\begin{tabular}{llllll}
\hline Variance & Sum of Squares & df & Mean Square & F & Sig. \\
\hline Regression & 453.323 & 8 & 56.665 & 149.305 & $.000^{\text {a }}$ \\
Residual & 281.229 & 741 & .380 & & \\
Total & 734.552 & 749 & & & \\
\hline
\end{tabular}

Table 8. Regression coefficients

\begin{tabular}{|c|c|c|c|c|c|c|c|}
\hline \multirow[t]{2}{*}{ Coefficients } & \multicolumn{2}{|c|}{$\begin{array}{l}\text { Unstandardized } \\
\text { Coefficients }\end{array}$} & \multirow{2}{*}{$\begin{array}{l}\text { Standardized } \\
\text { Coefficients } \\
\text { Beta }\end{array}$} & & \multirow{2}{*}{$\begin{array}{l}\text { Sig. } \\
\text { (1-tailed }\end{array}$} & \multirow{2}{*}{$\begin{array}{l}\text { Collinearity } \\
\text { Statistics } \\
\text { 1) Tolerance }\end{array}$} & \multirow{2}{*}{ VIF } \\
\hline & B & Std. Error & & & & & \\
\hline (Constant) & .168 & 1.036 & .051 & 1.036 .051 & 0.025 & & \\
\hline General Belief & .136 & 4.895 & .000 & 4.895 .000 & 0.000 & .624 & 1.602 \\
\hline Info. Quality & .103 & 3.158 & .002 & 3.158 .002 & 0.001 & .535 & 1.871 \\
\hline Website Design & .113 & 3.490 & .001 & 3.490 .001 & 0.000 & .552 & 1.811 \\
\hline $\begin{array}{l}\text { Merchandise } \\
\text { Attributes }\end{array}$ & .011 & .360 & .719 & .360 .719 & 0.359 & .578 & 1.731 \\
\hline $\begin{array}{l}\text { Payment } \\
\text { Transection }\end{array}$ & .148 & 3.795 & .000 & 3.795 .000 & 0.000 & .362 & 2.763 \\
\hline Security and Privacy & $y .239$ & 6.933 & .000 & 6.933 .000 & 0.000 & .400 & 2.497 \\
\hline Delivery Service & .065 & 1.734 & .083 & 1.734 .083 & 0.041 & .386 & 2.592 \\
\hline Customer Service & .181 & 5.681 & .000 & 5.681 .000 & 0.000 & .472 & 2.119 \\
\hline
\end{tabular}

Dependent variable: Satisfaction

Independent variables: General Belief, Information Quality, Website Design, Merchandise Attributes, Payment transection, Security and Privacy, Delivery Service and Customer Service 
Furthermore, the finding in Table 8 indicates that all independent variables have a positive effect on consumer satisfaction. Among the eight independent variables, a total of seven independent variables, i.e., general belief, information quality, website design, merchandise attributes, payment transection, security and privacy, delivery services, and expected customer service have a significant (at 5\% level of significance) effect on consumer satisfaction among online apparel consumers in Malaysia.

\section{Discussions and Managerial Implication}

The finding shows that all factors are positively significant to overall satisfaction. Therefore, this study can conclude that all eight variables affect overall satisfaction in the context of online apparel businesses in Malaysia. The finding indicates that general belief, information quality, website design, merchandise attributes, payment transaction, security and privacy, expected delivery services, and expected customer service have a significant (at $5 \%$ level of significance) effect on consumer satisfaction. Prior study by Jeon (2009) identified five attributes that affect e-satisfaction such as content of the website, convenience, accessibility, security, and website design. Among the significant independent variables (based on standardized regression coefficients, as noted in Table 8), expected delivery services, information quality, and website design have a higher effect on customer satisfaction. The apparel industry should therefore focus more on these three areas. According to Ali, Abu and Azadeh (2013), if customers do not have any difficulties in accessing the quality of the information through the website, it will lead to their satisfaction towards the website. This is supported by Yuan and Chu (2013) who stated that information quality is found to be an important role in determining customer satisfaction. Besides, Gregory, Wang and DiPietro (2010) believed that the design of the website is associated with consumer perception of the organization and the order at the site. Besides having sufficient information and a good website design, Guo et al. (2012) believes that merchandise attributes play a significant role in whether customers are satisfied or dissatisfied with their shopping experiences. Theoretically, the finding supports previous theory such as The theory of reasoned action (TRA) by Fishbein and Ajzen (1975) where people make decisions regarding on the information available to them and the best immediate determinant of a person's behavior is intent is the cognitive representation of readiness to perform certain behavior. In other words, for instance, information quality provided by the website is reliable and accurate, then this will increase online satisfaction

Specifically, this study helps the marketing practitioners in Malaysia to better understand their consumers on what is the best e-service attraction they can offer as well as how to react with it in the online environment. In other words, online retailers must to ensure that their website is well designed for instance easy to use, simple and convenient. As the finding indicate that instead of website design, expected customer service and information quality are other two elements contribute to satisfaction. Taking this into consideration, the online retailers in Malaysia must to ensure that the delivery service they provide must convenience for them and the information provided in the website should be updated regularly. Since this study corresponds with a previous study by White (2010), which revealed that all the factors have a significant impact on satisfaction - managers should take this into consideration for maintaining and improving their competitive advantage. Olorunniwo et al. (2006) added that managers should plan operational strategies which focus on the dimensions of service quality that boost customer satisfaction which can in turn lead to positive behavioral intentions. If customers are satisfied with the service, they will become loyal, revisit, and recommend to others. Furthermore, managers can use this framework to create benchmarks against which they can evaluate their own website. By doing so, they can identify their competitive strengths and weaknesses from the customers' viewpoints regarding the e-service quality, satisfaction, and intention at the time when customers make their purchase (point-of-purchase).

\section{References}

Ali, A., Bakar, A. A. H. A., \& Azadeh, A. (2013). The determinants of e-relationship quality on e-satisfaction in hotel websites. Elixir Human Resource Management, 56(A), 13824-13828.

Bauer, H. H., Falk, T., \& Hammerschmidt, M. (2006). E-Tranquil: A transaction process-based approach for capturing service quality in online shopping. Journal of Business Research, 59, 866-875. http://dx.doi.org/ 10.1016/j.jbusres.2006.01.021

Chen, H., Liu, J. Y., Sheu, T. S., \& Yang, M. (2012). The Impact of Financial Services Quality And Fairness On Customer Satisfaction. Managing Service Quality, 22(4), 399-421. http://dx.doi.org/10.1108/09604521 211253496

Chow, A. S., Bridges, M., \& Commander, P. (2014). The website design and usability of US academic and public libraries. Findings from a Nationwide study. Reference and User Services Quarterly, 53(3), 253-265. http://dx.doi.org/10.5860/rusq.53n3.253

Coker, B. (2013). Antecedents to website satisfaction, loyalty, and word-of-mouth. Journal of Information 
Systems and Technology Management, 10(2), 209-218. http://dx.doi.org/10.4301/S1807-177520 13000200001

Devaraj, S., Fan, M., \& Kohli, R. (2002). Antecedents of B2C channel satisfaction and preference: Validating e-commece metrics. Journal of Information Systems Research, 12(3), 316-333. http://dx.doi.org/10.1287 /isre.13.3.316.77

Eid, M. I. (2011). Determinants of e-commerce customer satisfaction, trust, and loyalty in saudi arabia. Journal of electronic commerce research, 12(1), 78-93.

Fishbein, M., \& Ajzen, I. (1975). Belief, Attitude, Intention and Behavior: An Introduction to Theory and Research. Addison-Wesley.

Garver, M. S., \& Gagnon, G. B. (2002). Seven keys to improving customer satisfaction programs. Business Horizons, 45(5), 35-42. http://dx.doi.org/10.1016/S0007-6813(02)00241-0

Gregory, A., Wang, Y. R., \& DiPietro, R. B. (2010). Towards a functional model of website evaluation: A case study of casual dining restaurants. Worldwide Hospitality and Tourism Themes, 2(1), 68-85. http://dx.doi. org $/ 10.1108 / 17554211011012603$

Guo, X., Ling, K. C., \& Liu, M. (2012). Evaluating Factors Influencing Consumer Satisfaction towards Online Shopping in China. Asian Social Science, 8(13), 40-50. http://dx.doi.org/10.5539/ass.v8n13p40

Han, J., \& Mills, J. E. (2006). Zero acquaintance benchmarking at travel destination websites: What is the first impression that national tourism organizations try to make? International Journal of Tourism Research, 8(6), 405-430. http://dx.doi.org/10.1002/jtr.581

Han, K. S., \& Noh, M. H. (2000). Critical failure factors that discourage the growth of electronic commerce. International Journal of Electronic Commerce, 4(2), 25-43.

Hirst, A., \& Ashwin, M. (2009). Cross Cultural Difference between Online Shoppers in London and Bangkok. Retrieved July 20, 2013, from http://uhra.herts.ac.uk/bitstream/handle/2299/2259/902371.pdf?sequence=1

Jeon, M. (2009). Conceptualizing web site quality and its consequences in the lodging industry. International Journal of Hospitality Management, 22(2), 161-175. http://dx.doi.org/10.1016/S0278-4319(03)00016-1

Kim, H., Hwang, Y., \& Fesenmaier, D. R. (2005). Modeling tourism advertising effectiveness. Journal of Travel Research, 44(1), 42-49. http://dx.doi.org/10.1177/0047287505276590

Kim, M., \& Stoel, L. (2004). Apparel retailers: Web site quality dimensions and satisfaction. Journal of Retailing and Consumer Services, 11, 109-117. http://dx.doi.org/10.1016/S0969-6989(03)00010-9

Kim, M., Kim, J. H., \& Lennon, S. (2006). Online service attributes available on apparel retail web sites: An E-S-QUAL approach. Managing Service Quality, 16(1), 51-77. http://dx.doi.org/10.1108/0960452061 0639964

Kuo, H. M., \& Chen, C. W. (2011). Application of quality function deployment to improve the quality of internet shopping website interface design. International Journal of Innovative Computing, Information and Control, 7(1), 253-268.

Ladhari, R. (2010). Developing e-service quality scales: A literature review. Journal of Retailing and Consumer Services, 17(6), 464-477. http://dx.doi.org/10.1016/j.jretconser.2010.06.003

Lau, T. C., Kwek, C. L., \& Tan, H. P. (2011). Airline e-Ticketing Service: How a Service Quality and Customer Satisfaction Impacted Purchase Intention. International Business Management, 5(4), 200-208. http://dx.doi. org/10.3923/ibm.2011.200.208

Leen, J. Y. A., \& Ramayah, T. (2011). Validation of the RSQS in apparel specialty stores. Measuring Business Excellence, 15(3), 16-18. http://dx.doi.org/10.1108/13683041111161139

Li, N., \& Zhang, P. (2006). What makes customers shop online? The technology of electronic customer relationship management. India: Pearson.

Lin, T. R. G., \& Chia, C. S. (2009). Factors influencing satisfaction and loyalty in online shopping: An integrated model. Online Information Review, 33(3), 458-475. http://dx.doi.org/10.1108/14684520910969907

Lopes, A. B., \& Galletta, D. F. (2006). Consumer perceptions and willingness to pay for intrinsically motivated online content. Journal of Management Information Systems, 23(2), 203-231. http://dx.doi.org/10.2753/ MIS0742-1222230209

Martin, S. S., Camarero, C., \& Jose, R. S. (2011). Does involvement matter in online shopping satisfaction and trust? Psychology and Marketing, 28(2), 145-167. http://dx.doi.org/10.1002/mar.20384 
Mumtaz, H., Islam, M. A., Ariffin, K. H. K., \& Anayet, K. (2011). Customer Satisfaction on Online Shopping in Malaysia. International Journal of Business and Management, 6(10), 162-169. http://dx.doi.org/10.5539 /ijbm.v6n10p162

Muyllea, S., Moenaert, R., \& Despontin, M. (2004). The conceptualization and empirical validation of web site user satisfaction. Journal of Information and Management, 41, 543-560. http://dx.doi.org/10.1016/S0378 $-7206(03) 00089-2$

Nikhashemi, S. R., Haque, A., Yasmin, F., \& Khatibi, A. (2012). Service quality and influencing factor on consumer purchase intention of online Ticketing: An empirical study in Iran. Business Management Dynamics, 1(7), 22-30.

Olorunniwo, F., Hsu, M. K., \& Udo, G. J. (2006). Service quality, customer satisfaction and behavioral intentions in the service factory. Journal of Services Marketing, 20(1), 59-72. http://dx.doi.org/10.1108/08876040 610646581

Parasuraman, A., Zeithaml, V. A., \& Malhotra, A. (2005). E-SQUAL: A multiple-item scale for measuring consumer perceptions for service quality. Journal of Retailing, 7(3), 12-40.

Rajamma, R. K., \& Neeley, C. R. (2005). Antecedents to shopping online: A Shopping Preference Perspective. Journal of Internet Commerce, 4(1), 63-78. http://dx.doi.org/10.1300/J179v04n01_03

Ray, R. (2010). Supply chain management for retailing. New Delhi: Tata McGraw-Hill.

Rossiter, J.n R. (2002). The C-OAR-SE Procedure for Scale Development in Marketing. International Journal of Research in Marketing, 19, 305-335. http://dx.doi.org/10.1016/S0167-8116(02)00097-6

Swinyard, W. R., \& Smith, S. M. (2003). Why People Don't Shop Online: A Lifestyle Study of the Internet Consumers. Psychology and Marketing, 20(7), 567-597. http://dx.doi.org/10.1002/mar.10087

Szymanski, D. M., \& Hise, R. T. (2000). E-satisfaction: An initial examination. Journal of Retailing, 76(3), 309-322. http://dx.doi.org/10.1016/S0022-4359(00)00035-X

Teo, H. H., Oh, L. B., Liu, C., \& Wei, K. K. (2003). An empirical study of the effect of interactivity on web user attitude. International Journal of Human-Computer Studies, 58(3), 281-305. http://dx.doi.org/10.1016/S1 071-5819(03)00008-9

Vijayasarathy, L. R. (2004). Predicting consumer intentions to use on-line shopping: The case for an augmented technology acceptance model. Information and Management, 41(6), 747-762. http://dx.doi.org/10.1016/j. im.2003.08.011

Wang, M., \& Huarng, A. S. (2002). An Empirical Study of the Internet Store Customer Post-Shopping Satisfaction. Special Issues of Information Systems, 3, 632-638.

Wirtz, J., Chew, P., \& Lovelock, C. (2012). Pre Purchase Stage Essentials of Services Marketing (2nd ed.). Pearson Education.

Wolfinbarger, M. F., \& Gilly, M. C. (2003). ETAILQ: Dimensionalizing, measuring and predicting e-tailing quality. Journal of Retailing, 79(3), 183-198. http://dx.doi.org/10.1016/S0022-4359(03)00034-4

Wu, C. C. (2011). The impact of hospital brand image on service quality, patient satisfaction and loyalty. African Journal of Business Management, 5(12), 4873-4882.

Xia, L. M., He, Fang, G., \& Peihong, X. (2008). An empirical study of online shopping customer satisfaction in China: a holistic perspective. International Journal of Retail and Distribution Management, 36(11), 919-940. http://dx.doi.org/10.1108/09590550810911683

Yoon, C. (2010) Antecedents of Customer Satisfaction with Online Banking in China: The effects of Experience. Computers in Human Behavior, 26, 1296-1304. http://dx.doi.org/10.1016/j.chb.2010.04.001

Yuan, X., \& Kyounghee, C. (2013). When and how information quality matters: Perceived customer orientation and customer satisfaction. Advances in Information Sciences and Service Sciences, 5(9), 105-113. http://dx.doi.org/10.4156/aiss.vol5.issue9.13

\section{Copyrights}

Copyright for this article is retained by the author(s), with first publication rights granted to the journal.

This is an open-access article distributed under the terms and conditions of the Creative Commons Attribution license (http://creativecommons.org/licenses/by/3.0/). 